\title{
Cav 1.2 and Cav 2.2 expression is regulated by different endogenous ghrelin levels in pancreatic acinar cells during acute pancreatitis
}

\author{
JIE ZHOU*, MENGBIN QIN*, HUILIN WANG, JIAPING HE, HONGZONG FU, \\ HUIRONG SHI, ZHIHAI LIANG and GUODU TANG \\ Department of Gastroenterology, The First Affiliated Hospital, Guangxi Medical University, \\ Nanning, Guangxi 530021, P.R. China
}

Received September 21, 2016; Accepted February 7, 2018

DOI: $10.3892 / \mathrm{ijmm} .2018 .3490$

\begin{abstract}
Ghrelin influences pancreatic endocrine and exocrine functions, regulates intracellular calcium $\left[\mathrm{Ca}^{2+}\right]_{\mathrm{i}}$ levels, and has an anti-inflammatory role in acute pancreatitis. This study investigated the role of endogenous ghrelin in the expression of Cav 1.2 (L-type of $\mathrm{Ca}^{2+}$ channel) and Cav 2.2 (N-type of $\mathrm{Ca}^{2+}$ channel) in acute pancreatitis. For this purpose, acute edematous pancreatitis (AEP) and acute necrotizing pancreatitis (ANP) rat models were established. Cav 1.2 and Cav 2.2 expression was assessed by immunohistochemistry in the pancreatic tissues of rats; ghrelin, interleukin-1 $\beta$ (IL-1 $\beta$ ) and tumor necrosis factor- $\alpha$ (TNF- $\alpha$ ) serum levels were detected using ELISA. Next, in AR42J cells with either knock-out or overexpression of ghrelin, Cav 1.2 and Cav 2.2 expression was examined using western blot analysis, and intracellular calcium $\left[\mathrm{Ca}^{2+}\right]_{\mathrm{i}}$ was detected with confocal microscopy. In this study, the ghrelin serum level was highest in the ANP group and was higher in the AEP group than the normal group. Expression of Cav 1.2 and Cav 2.2 in the ANP and AEP groups was higher than in the respective control groups. The serum IL-1 $\beta$ and TNF- $\alpha$ levels were significantly higher in the ANP group compared to the other groups. Cav 1.2 and Cav 2.2 expression and $\left[\mathrm{Ca}^{2+}\right]_{\mathrm{i}}$ decreased in ghrelin knockdown AR42J cells but increased in ghrelin overexpressing cells. In conclusion, Cav 1.2 and Cav 2.2 expression increased in ANP. The $\left[\mathrm{Ca}^{2+}\right]$ i level, which is mediated by Cav 1.2 and Cav 2.2 expression, is directly regulated by ghrelin in pancreatic acinar cells, and serum ghrelin levels may be involved in the severity of acute pancreatitis.
\end{abstract}

Correspondence to: Professor Guodu Tang, Department of Gastroenterology, The First Affiliated Hospital, Guangxi Medical University, 6 Shuangyong Road, Nanning, Guangxi 530021, P.R. China E-mail: tguodu02@126.com

*Contributed equally

Key words: calcium channels, Cav 1.2, Cav 2.2, ghrelin, acute pancreatitis

\section{Introduction}

Acute pancreatitis (AP) is an inflammatory disorder of the pancreas, with an incidence of 13 to $45 / 100,000$ people (1). AP has been reported as one of the most frequent principal gastrointestinal discharge diagnoses in the USA (2). According to the 2012 Atlanta classification for acute pancreatitis, there are three types of AP: mild acute pancreatitis (MAP), moderately acute pancreatitis and severe acute pancreatitis (SAP), which are defined based on the extent of organ failure and its duration (3). MAP is self-limiting, but SAP is a life-threatening condition with a high mortality rate and rapid progression that is associated with many complications (4). Several mechanisms of pancreatic damage have been proposed in recent studies, such as pancreatic duct obstruction, trypsinogen activation, pancreatic microcirculation malfunction (5), calcium $\left(\mathrm{Ca}^{2+}\right)$ overload (6) and the activation of inflammatory pathways (7).

Under normal physiological conditions, $\mathrm{Ca}^{2+}$ signals are transient and localized in granules at the apical pole; however, the sustained elevation of cytosolic $\mathrm{Ca}^{2+}$ concentrations is fatal $(8,9) . \mathrm{Ca}^{2+}$ cell entry is mediated by voltage-dependent $\mathrm{Ca}^{2+}$ channels (principally L-type $\mathrm{Ca}^{2+}$ channels) and is involved in a variety of $\mathrm{Ca}^{2+}$-dependent processes, including muscle contraction, hormone or neurotransmitter release and gene expression (10). In recent years, $\mathrm{Ca}^{2+}$ overload has received increasing attention, and its role is being extensively investigated in the context of pancreatic acinar cells injury (11). Digestive enzymes have been reported to be produced by pancreatic acinar cells and packaged in zymogen granules in the apical pole (12). When $\mathrm{Ca}^{2+}$ overload occurs, it activates several signaling pathways, including mitogen-activated protein kinases, phosphoinositide 3-kinase, and nuclear factor- $\mathrm{kB}(\mathrm{NF}-\mathrm{kB})$ cascades, which leads to the induction of several proinflammatory mediators (13). However, $\mathrm{Ca}^{2+}$ overload causes intracellular trypsin activation, vacuolization and necrosis (14-16), which aggravates subsequent cell injury and increases mortality in human acute pancreatitis (17). Voltagedependent $\mathrm{Ca}^{2+}$ channels have recently been demonstrated to be regulated by growth hormone secretagogue receptor type 1a (GHSR1a). Ghrelin-dependent GHSR1a inhibition is reversible and involves the altered function of $\mathrm{Ca}^{2+}$ channels 
via $\mathrm{G}_{\mathrm{i} / \mathrm{o}}$ or $\mathrm{G}_{\mathrm{q}}$ signaling pathways (18). Voltage-gated ion channels are widely known to be involved in the control of growth hormone (GH) synthesis and release (19). The molecular basis of these regulatory actions has not been determined.

Ghrelin is a novel GH-releasing peptide that was initially isolated from gastric X/A-like cells and is a natural ligand for GHSR (20). Acute treatment with ghrelin increases intracellular calcium $\left[\mathrm{Ca}^{2+}\right]_{\mathrm{i}}(21)$. In somatotropes, this may upregulate voltage-activated $\mathrm{Ca}^{2+}$ influx in a larger time scale through activated L-type $\mathrm{Ca}^{2+}$ channels (22). Several studies showed that ghrelin has an anti-inflammatory role in acute pancreatitis due to its involvement in NF- $\kappa \mathrm{B}$ inhibition, an increase in pancreatic blood flow and DNA synthesis, anti-oxidation, and the stimulation of pancreatic cell proliferation (23-25). However, the molecular mechanism of endogenous ghrelin calcium channel regulation in pancreatic acinar cells in acute pancreatitis remains unclear. Therefore, this study examined the level of serum ghrelin in acute edematous pancreatitis (AEP) and acute necrotizing pancreatitis (ANP) rat models. Additionally, Cav 1.2 (L-type of $\mathrm{Ca}^{2+}$ channel) and Cav 2.2 (N-type of $\mathrm{Ca}^{2+}$ channel) expression were examined in rat pancreatic tissues and transfected AR42J cells with ghrelin overexpression and knockdown.

\section{Materials and methods}

Antibodies and reagents. Antibody against ghrelin (cat. no. ab134978) was purchased from Abcam PLC (Cambridge, MA, USA). Antibodies against Cav 1.2 (cat. no. sc-16229-R) and Cav 2.2 (cat. no. sc-20129) were purchased from Santa Cruz Biotechnology, Inc. (Dallas, TX, USA). Antibody against glyceraldehyde 3-phosphate dehydrogenase (GAPDH) (cat. no. 2118) was purchased from Cell Signaling Technology (Beverly, MA, USA). Pierce ECL Western Blotting Substrate (cat. no. 32209) was obtained from Thermo Fisher Scientific (Waltham, MA, USA). Blasticidin (cat. no. 203351) was purchased from EMD Millipore (Darmstadt, Germany). Fluo-4/AM (cat. no. F14217) was purchased from Invitrogen (Grand Island, NY, USA). The kit for enzyme-linked immunosorbent assay (ELISA) ghrelin detection (cat. no. EIA-GHR) was purchased from RayBiotech, Inc. (Norcross, GA, USA). Interleukin-1 $\beta$ (IL-1 $\beta$ ) (cat. no. ERC007.96) and TNF- $\alpha$ (cat. no. ERC102a.96) ELISA kits were purchased from Neobioscience Biotechnology (Shenzhen, China). Caerulein and sodium taurocholate were purchased from Sigma-Aldrich Co. (St. Louis, MO, USA).

Animal groups. For the in vivo experiments, 40 healthy male Sprague-Dawley rats weighing 200-250 g were purchased from the Guangxi Medical University Animal Experimentation Center, China (certificate no. SCXK GUI 2009-0002). All rats were maintained in an environment with controlled temperature $\left(20-24^{\circ} \mathrm{C}\right)$ and humidity $(55-58 \%)$, a 12-h light/dark cycle and fed with standard pellet rat food $(210 \mathrm{kcal} / 100 \mathrm{~g} /$ day $)$. Before each experiment, the animals were fasted overnight but allowed free access to water. The following day, the rats were randomly divided into five groups: the normal group, an acute edematous pancreatitis (AEP) group, an AEP-control group, an acute necrotizing pancreatitis (ANP) group and an ANP-control group.
Acute pancreatitis rat models and pathological scores of pancreatic tissues. In this study, AEP was induced by the administration of $50 \mu \mathrm{g} / \mathrm{kg}$ of caerulein with intraperitoneal injections five times per day in 1-h intervals, and the same volume of normal saline was injected intraperitoneally in the AEP control rats. ANP was induced by the injection of $1 \mathrm{ml} / \mathrm{kg}$ of $5 \%$ sodium taurocholate into a biliopancreatic duct for $5 \mathrm{~min}$, following the closure of the surgical incision with a double layer of stitching. After the operation, the rats were subcutaneously injected with $30 \mathrm{ml} / \mathrm{kg}$ of the same volume of normal saline. The pancreas and duodenum treatments were switched as in the ANP control group. After surgery, the rats were provided with water ad libitum. Next, all rats were anesthetized and blood samples $(2 \mathrm{ml})$ were collected from the inferior vena cava $24 \mathrm{~h}$ following surgery or from the last intraperitoneal injection. All animals were checked daily to monitor their health. They were finally euthanized by cervical dislocation. All animal care and studies were conducted in accordance with the approval of the Medical Ethics Committee of the First Affiliated Hospital of Guangxi Medical University for Ethical Approval for Research Involving Animals (Nanning, China, permit no. KY-113). All surgeries were performed under 10\% chloral hydrate, and all efforts were made to minimize suffering. Pancreatic tissue was excised and fixed in $10 \%$ formalin and embedded in paraffin. For pathological observation, tissue blocks were cut into sections and stained with hematoxylin and eosin. A double-blind microscopic analysis was performed by two senior pathologists. Pathological scores for pancreatic tissues on a scale from 0 to 4 were determined with regard to the degree of edema, inflammation, hemorrhage and necrosis according to the method described by Kusske et al (26).

Cell culture and transfection. For the in vitro experiments, the rat pancreatic exocrine cell line AR42J was obtained from American Type Culture Collection (Manassas, VA, USA) and used for stable ghrelin overexpression or knockdown transfections. In brief, AR42J cells were grown in high glucose Dulbecco's modified Eagle's medium (Invitrogen) supplemented with $10 \%$ fetal bovine serum (FBS) and penicillin/streptomycin $(100 \mathrm{U} / \mathrm{ml})$ in an atmosphere of $5 \% \mathrm{CO}_{2}$ at $37^{\circ} \mathrm{C}$. In this study, cells were transfected with ghrelin-overexpressing vector, knockdown ghrelin short hairpin RNA (shRNA) vector or blank vector [negative control (NC)]. Lentiviral vector encoding human ghrelin was generated by cloning ghrelin PCR fragments (full sequence) into a pcDNA3.1-GFP vector (Invitrogen) through EcoRI/XhoI digestion sites. The ghrelin shRNA (3'-AGAAAGGAATCCAAGAAGCCACC-5', 5'-TGCCAACA TCGAAGGGAGC-3') was cloned into a pcDNA6.2-EGFPghrelin-miR vector (Invitrogen). For the lentiviral infection of cells, cells were cultured in medium and inoculated with lentivirus at a multiplicity of infection (MOI) of 10 for $48 \mathrm{~h}$, and the percentage of cells that became infected at this MOI was $\sim 95 \%$. Blasticidin $\mathrm{S}(0.2 \mu \mathrm{g} / \mathrm{ml})$ was added into the medium for 2 weeks followed by another 2 weeks at $0.1 \mu \mathrm{g} / \mathrm{ml}$. Stable ghrelin overexpression or knockdown cell lines were then isolated via fluorescence-activated cell sorting and verified using western blot analysis. Finally, stably transfected AR42J cell clones with ghrelin overexpression or knockdown were chosen for subsequent experiments. 
Western blot analysis. In this study, the protein expression of ghrelin, Cav 1.2, and Cav 2.2 in AR42J cells was examined using western blot analysis. For western blot analysis, cells were lysed in Triton X-100-based lysis buffer. The protein concentration in the supernatant was determined using Bradford colorimetry. Next, $40 \mu \mathrm{g}$ of protein from each sample was denatured and separated using sodium dodecyl sulfate-polyacrylamide gel electrophoresis (SDS-PAGE) and electroblotted onto a PVDF membrane (Bio-Rad, Hercules, CA, USA). Following blocking in 5\% non-fat milk in TBST for $1 \mathrm{~h}$, the membranes were incubated overnight at $4^{\circ} \mathrm{C}$ with appropriate antibodies as follows: ghrelin (diluted 1:250), Cav 1.2 (diluted 1:300), Cav 2.2 (diluted 1:300) and GAPDH (diluted $1: 3,000)$. After washing with phosphate-buffered saline (PBS), PVDF membranes were incubated with goat anti-rabbit horseradish peroxidase (HRP)-conjugated secondary antibody $(1: 2,000)$ (Santa Cruz Biotechnology, Inc.) for 2 h. Protein signals were visualized using enhanced chemiluminescence reagents according to the manufacturer's instructions. Optical density of the imaged bands was normalized using a GAPDH signal obtained on the same blot. The data were summarized as the means \pm SD of three independent experiments.

Immunohistochemistry. All pancreatic tissue samples were fixed with $4 \%$ paraformaldehyde for $12 \mathrm{~h}$, embedded in paraffin and cut into $4-\mu \mathrm{m}$ sections. For the immunohistochemical analysis, sections were deparaffinized, rehydrated, and endogenous peroxidases were blocked in methanol with $3 \% \mathrm{H}_{2} \mathrm{O}_{2}$ for $10 \mathrm{~min}$. After antigen retrieval induced by heat in a microwave at $93^{\circ} \mathrm{C}$ for $30 \mathrm{~min}$, sections were blocked in $10 \%$ normal goat serum for $1 \mathrm{~h}$ and incubated with primary antibody (Cav 1.2, diluted 1:100; Cav 2.2, diluted 1:100) for $4 \mathrm{~h}$. Next, biotinylated secondary antibody (Santa Cruz Biotechnology, Inc.) was applied for $30 \mathrm{~min}$. The immunohistochemical reaction was visualized using $0.01 \%$ DAB chromogen (Santa Cruz Biotechnology, Inc.) for $2 \mathrm{~min}$. All slides were evaluated by two pathologists. Evaluation of the staining reaction was performed in accordance with the immunoreactive score (IRS) (27): IRS = SI (staining intensity) x PP (percentage of positive cells). SI was defined as 0 , negative; 1 , weak; 2 , moderate; and 3 , strong. PP was defined as 0 , no positive cells present; $1,10 \%$ positive cells; $2,11-50 \%$ positive cells; $3,51-80 \%$ positive cells; and 4 , $>80 \%$ positive cells. Ten visual fields from different areas of each tissue were used for IRS evaluation. Pancreatic tissue slides with at least 3 IRS points in this study were classified as immunoreactive.

$\left[\mathrm{Ca}^{2+}\right]_{i}$ imaging in the AR42J cells. For $\left[\mathrm{Ca}^{2+}\right]_{\mathrm{i}}$ imaging, AR42J cells were seeded in a 24 -well culture plate containing glass coverslips for $24 \mathrm{~h}$ and fixed with $4 \%$ formaldehyde. Next, the cells were washed three times with PBS and incubated in $5 \mu \mathrm{M}$ fluo-4/AM (Invitrogen) for $30 \mathrm{~min}$ at room temperature. The cells were then washed five times with PBS, antifade mounting medium was added and cells were examined under fluorescence microscope (IX83 system; Olympus, Tokyo, Japan). Fluo-4 was excited at $495 \mathrm{~nm}$, and fluorescence emissions were separately collected at $510 \mathrm{~nm} .\left[\mathrm{Ca}^{2+}\right]_{\mathrm{i}}$ was quantified from fluo-4 levels (red fluorescence). Each sample was analyzed three times.
Enzyme-linked immunosorbent assay (ELISA). Levels of ghrelin, IL-1 $\beta$ and TNF- $\alpha$ in rat serum were measured using commercially available ELISA kits according to the manufacturer's instructions. In brief, supernatants were collected at the $24 \mathrm{~h}$ time point and centrifuged at 1,500 rpm for $20 \mathrm{~min}$. Next, a $100-\mu 1$ aliquot of supernatant, standard sample, or positive control sample was added into a 96-well plate and incubated for $1 \mathrm{~h}$ at $37^{\circ} \mathrm{C}$. Then, $100 \mu \mathrm{l}$ of enzyme-linked antibodies were added, and the plate was incubated for $30 \mathrm{~min}$ at $4^{\circ} \mathrm{C}$. After washing nine times with washing buffer and incubation for $30 \mathrm{~min}$ at $37^{\circ} \mathrm{C}$, $2 \mathrm{M} \mathrm{H}_{2} \mathrm{SO}_{4}$ was added to terminate the reaction. Absorbance at $450 \mathrm{~nm}$ was determined using a microplate reader (Thermo Fisher Scientific). Each sample was analyzed three times.

Statistical analysis. The data are presented as the means \pm SD. The statistical significance of differences between the means was evaluated using the one-way analysis of variance test. Statistical analysis was performed using SPSS 20.0 (IBM Corp., Armonk, NY, USA). A value of $\mathrm{p}<0.05$ was considered significant.

\section{Results}

Histopathological scores of pancreatic tissues, serum ghrelin, $I L-1 \beta$ and TNF- $\alpha$ in AEP and ANP rats. In this study, no obvious pathological changes were observed in the normal group, the AEP-control group or ANP-control group of animals (Fig. 1A-C). When pancreatic tissues of AEP rats were examined, fewer foci were observed. Additionally, hemorrhagic ascites in the pancreas and saponifying spots in the mesentery or the greater omentum were not observed in AEP rats. Under light microscope, edema and inflammatory cells infiltrating the pancreatic stroma were observed; nevertheless, diffuse bleeding and piecemeal necrosis did not appear in the pancreas of AEP rats (Fig. 1D).

However, hemorrhagic ascites, necrosis foci in the pancreas and several saponifying spots in the mesentery and greater omentum were observed in rats with ANP. Infiltrating inflammatory cells in the pancreatic stroma and glandular lobule, as well as diffuse bleeding and necrosis were also observed under light microscope in these rats (Fig. 1E). Pathohistological scores of pancreatic tissues in the ANP group were significantly higher than in the other groups $(\mathrm{p}<0.05)$. Additionally, these scores were also higher in the AEP group compared with the AEP-control and normal rats (Table I).

Furthermore, ghrelin serum levels were significantly increased in the ANP group compared with those in the other groups $(\mathrm{p}<0.05)$. Additionally, ghrelin serum levels in the AEP group were higher than the normal group and AEP-control group ( $\mathrm{p}<0.05$ ). Finally, IL-1 $\beta$ and TNF- $\alpha$ serum levels were significantly higher in the ANP group compared with the other groups $(\mathrm{p}<0.05)$ (Table I).

Expression of calcium channels in the pancreas of AEP and ANP rats. In this study, Cav 1.2 and Cav 2.2 expression in the pancreas of AEP and ANP rats were examined using immunohistochemistry. The IRS of Cav 1.2 and Cav 2.2 were higher in the ANP group compared with the ANP-control group $(\mathrm{p}<0.05)$. IRS scores in the AEP rats were higher than those obtained for the AEP-control and normal rats (Fig. 2 and Table I). 
Table I. Pathohistological scores of pancreatic tissues, serum levels of ghrelin, IL-1 $\beta$ and TNF- $\alpha$, and the IRS of Cav 1.2 and Cav 2.2 in AEP and ANP rats.

\begin{tabular}{|c|c|c|c|c|c|c|c|}
\hline Group & $\mathrm{N}$ & $\begin{array}{l}\text { Pathohistological } \\
\text { score }\end{array}$ & $\begin{array}{l}\text { Ghrelin } \\
(\mathrm{pg} / \mathrm{ml})\end{array}$ & $\begin{array}{c}\mathrm{IL}-1 \beta \\
(\mathrm{pg} / \mathrm{ml})\end{array}$ & $\begin{array}{l}\mathrm{TNF}-\alpha \\
(\mathrm{pg} / \mathrm{ml})\end{array}$ & $\begin{array}{l}\text { Cav } 1.2 \\
\text { IRS }\end{array}$ & $\begin{array}{l}\text { Cav } 2.2 \\
\text { IRS }\end{array}$ \\
\hline Normal & 6 & $0.33 \pm 0.52$ & $71.15 \pm 6.28$ & $40.45 \pm 7.05$ & $7.98 \pm 1.29$ & $1.76 \pm 0.57$ & $1.74 \pm 0.47$ \\
\hline AEP-control & 6 & $1.67 \pm 1.03$ & $74.94 \pm 11.95$ & $46.07 \pm 27.81$ & $9.34 \pm 3.15$ & $1.76 \pm 0.36$ & $1.74 \pm 0.33$ \\
\hline AEP & 6 & $4.50 \pm 1.64^{\mathrm{a}, \mathrm{b}}$ & $98.96 \pm 9.06^{\mathrm{a}, \mathrm{b}}$ & $67.52 \pm 25.38$ & $28.02 \pm 11.60$ & $3.69 \pm 0.52^{\mathrm{a}, \mathrm{b}}$ & $2.89 \pm 0.51^{\mathrm{a}, \mathrm{b}}$ \\
\hline ANP-control & 6 & $2.83 \pm 1.72$ & $87.11 \pm 7.90$ & $60.80 \pm 21.58$ & $14.70 \pm 5.47$ & $3.06 \pm 0.29$ & $3.56 \pm 0.58$ \\
\hline ANP & 6 & $10.83 \pm 2.04^{\mathrm{a}-\mathrm{d}}$ & $291.37 \pm 57.35^{\mathrm{a}-\mathrm{d}}$ & $182.82 \pm 65.28^{\mathrm{a}-\mathrm{d}}$ & $54.59 \pm 16.60^{\mathrm{a}, \mathrm{b}, \mathrm{d}}$ & $5.74 \pm 1.04^{\mathrm{a}-\mathrm{d}}$ & $5.74 \pm 1.04^{\mathrm{a}-\mathrm{d}}$ \\
\hline
\end{tabular}

${ }^{\mathrm{a}} \mathrm{vs}$. normal, $\mathrm{p}<0.05 ;{ }^{\mathrm{b}} \mathrm{Vs}$. AEP control, $\mathrm{p}<0.05 ;{ }^{\mathrm{c}} \mathrm{vs}$. AEP, $\mathrm{p}<0.05$; ${ }^{\mathrm{d} V \mathrm{~V}}$. ANP control, $\mathrm{p}<0.05$. IL- $1 \beta$, interleukin- $1 \beta$; TNF- $\alpha$, tumor necrosis factor- $\alpha$; IRS, immunoreactive score; AEP, acute edematous pancreatitis; ANP, acute necrotizing pancreatitis.
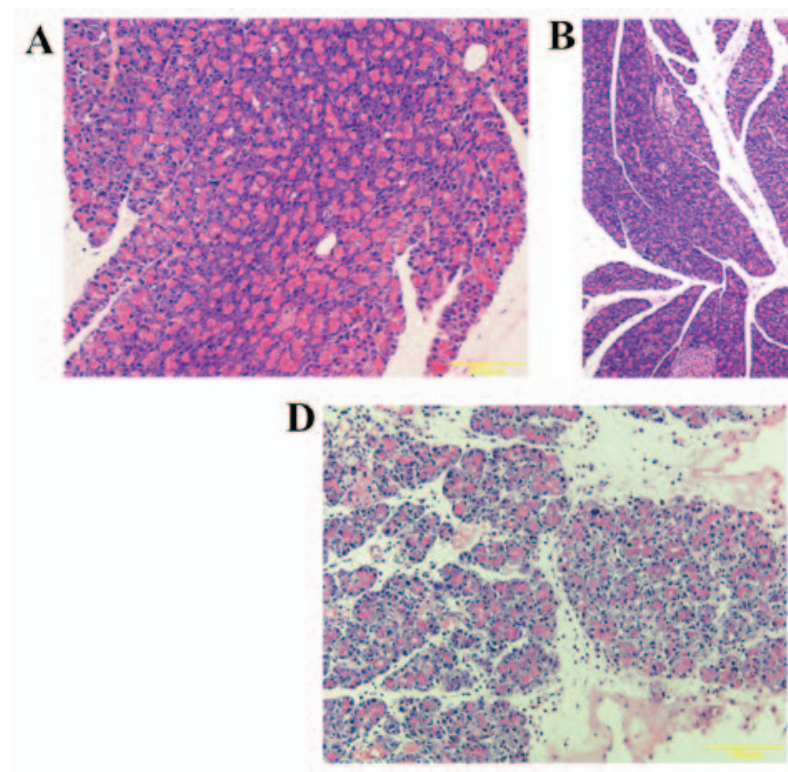
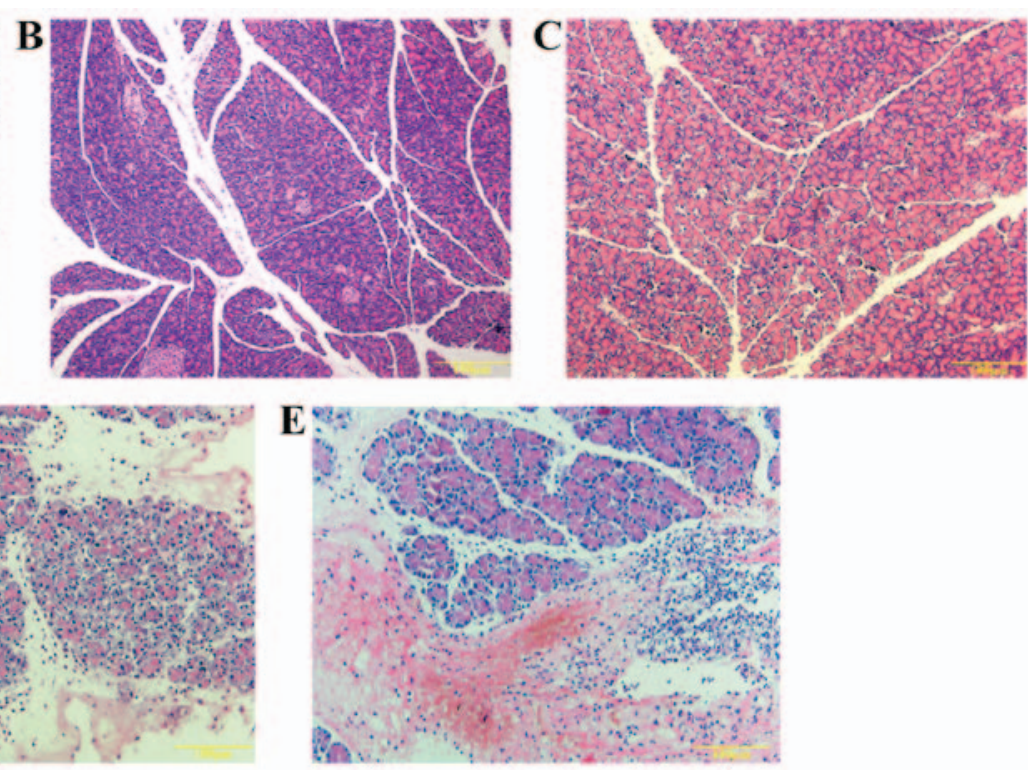

Figure 1. Histopathological analysis of pancreatic tissues in acute edematous pancreatitis (AEP) and acute necrotizing pancreatitis (ANP) rats. (A) Normal group. (B) AEP-control group. (C) ANP-control group. (D) AEP group: edema and inflammatory cells infiltrating the pancreatic stroma are visible, but diffuse bleeding and piecemeal necrosis are not present. (E) ANP group: infiltrating inflammatory cells in the pancreatic stroma and glandular lobule and diffuse bleeding and necrosis are detected.
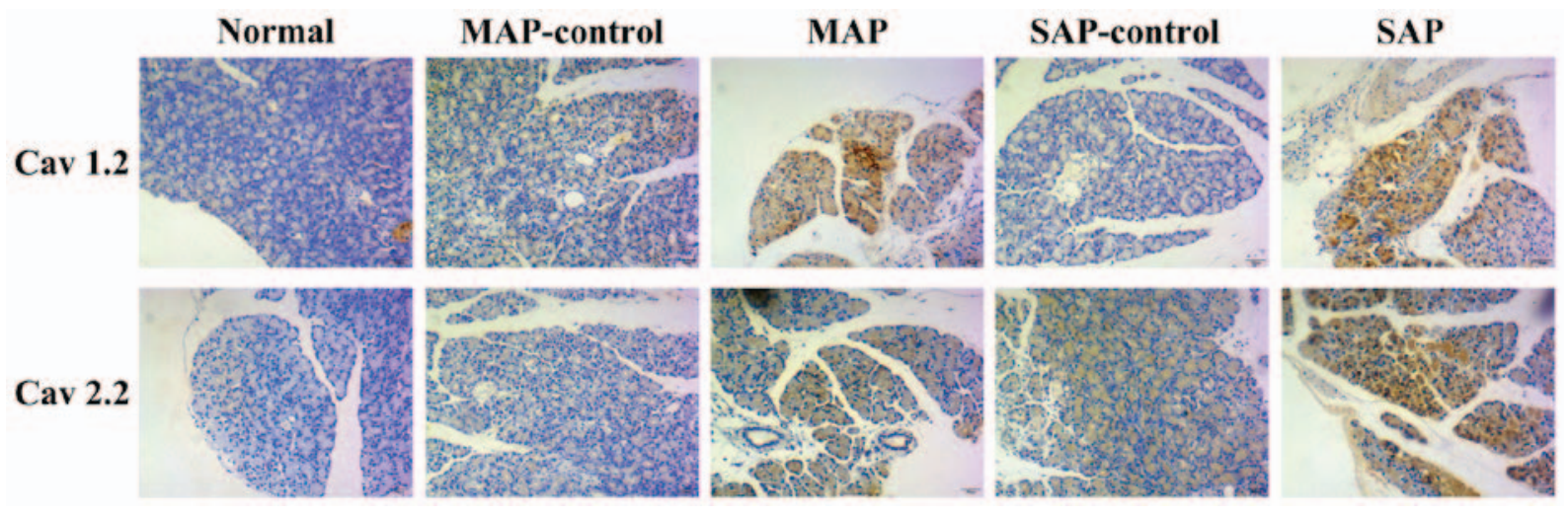

Figure 2. Expression of calcium channels in the pancreas of acute edematous pancreatitis (AEP) and acute necrotizing pancreatitis (ANP) rats. Expression of Cav 1.2 and Cav 2.2 was higher in the ANP rats compared with other groups. Additionally, the IRS scores of the AEP rats were higher than those obtained for the AEP-control and normal rats.

The expression of calcium channels in AR42J cells with endogenous ghrelin. In this study, stable ghrelin knockdown in AR42J cells resulted in low ghrelin protein expression, whereas cells transfected with an empty vector (ghrelin 
A

AR42J

AR42J

AR42J

+Ghrelin shRNA NC +Ghrelin shRNA

Ghrelin

GAPDH

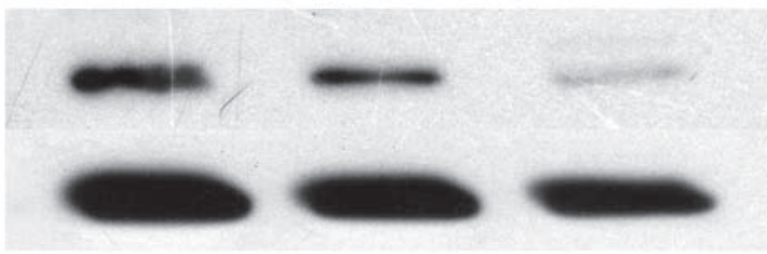

B

AR42J

AR42J +Ghrelin NC $\quad+$ Ghrelin

Ghrelin

GAPDH
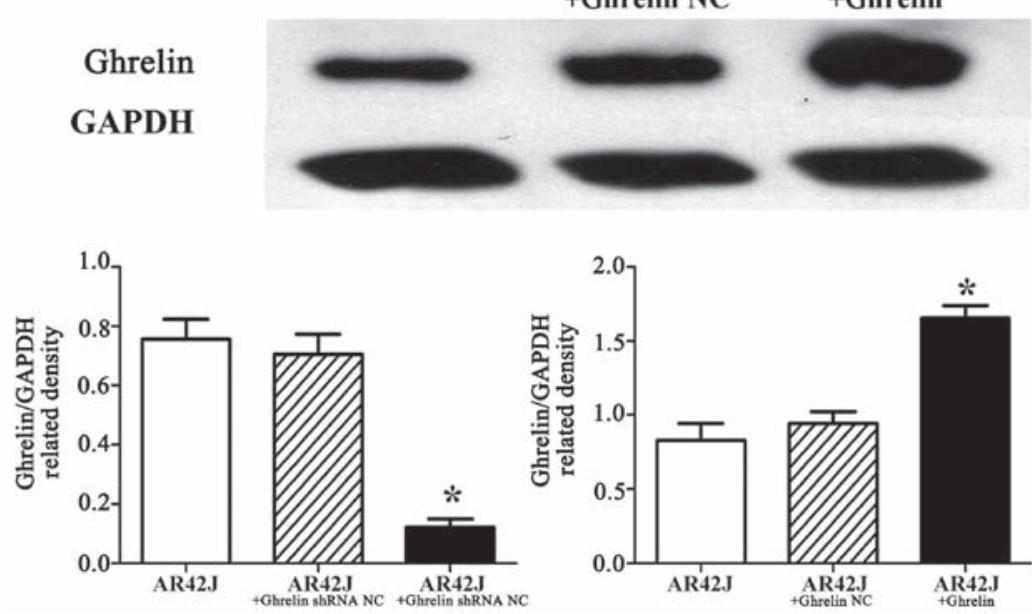

Figure 3. Lentivirus-mediated transfection of AR42J cells. (A) Expression of ghrelin in AR42J cells with ghrelin knockdown. (B) Expression of ghrelin in AR42J cells with ghrelin overexpression. AR42J cells transfected with an empty vector (NC) had ghrelin expression similar to the control untransfected AR42J cells, as determined with western blot analysis. AR42J transfected vs. untransfected AR42J, ${ }^{p}$ < $<0.05$.
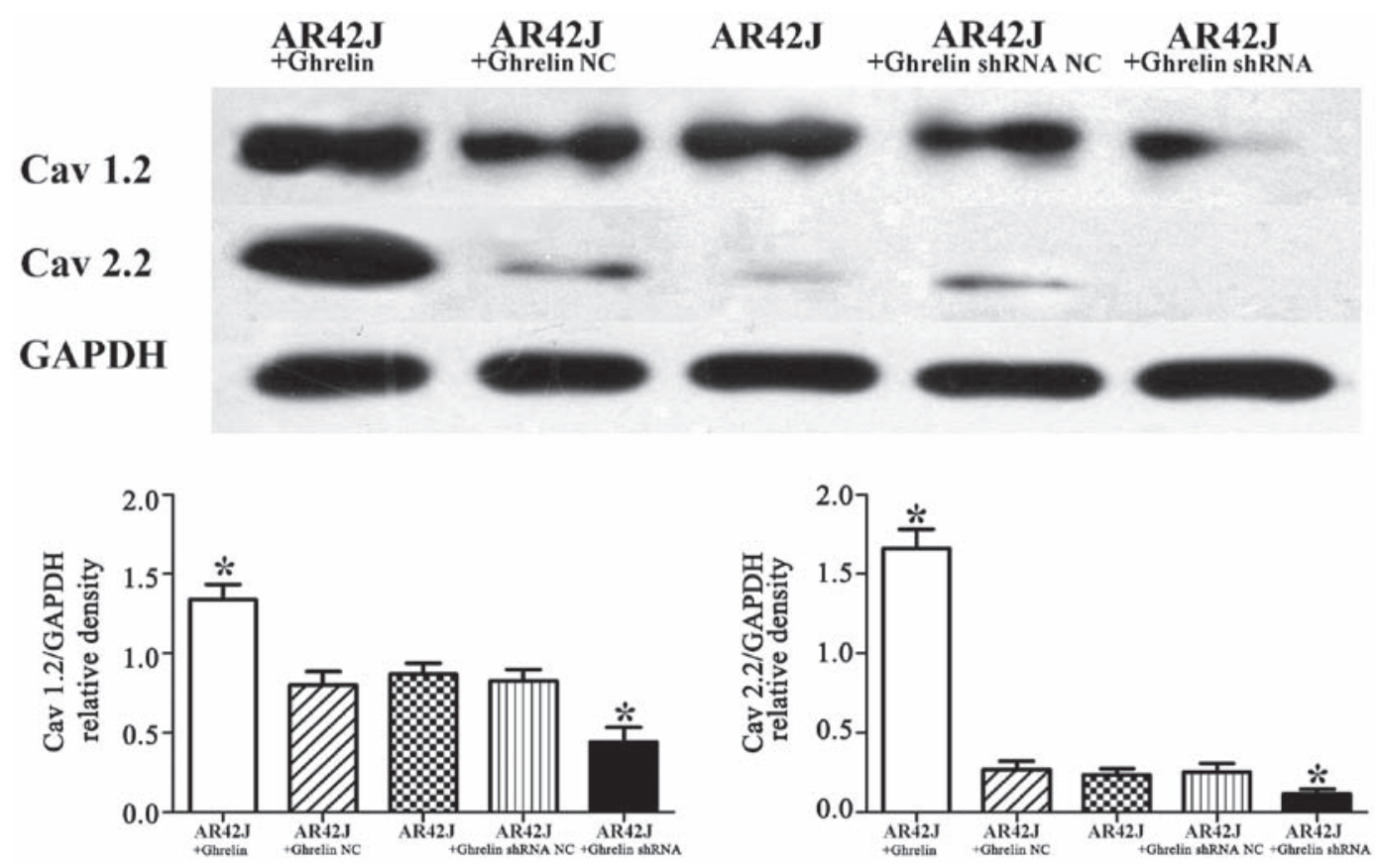

Figure 4. Endogenous ghrelin regulates the expression of calcium channels in AR42J cells. Control untransfected AR42J cells showed low Cav 1.2. and Cav 2.2 expression. Compared with control untransfected AR42J cells, Cav 1.2 and Cav 2.2 expression decreased in cells with ghrelin knockdown, whereas the expression of these two calcium channels increased in cells with ghrelin overexpression, as determined using western blot analysis. AR42J transfected vs. untransfected AR42J, ${ }^{*} \mathrm{p}<0.05$.

shRNA NC) had similar ghrelin expression as that detected for control untransfected AR42J cells $(\mathrm{p}<0.05)$ (Fig. 3A). Additionally, the stable ghrelin overexpression in AR42J cells resulted in high ghrelin expression, whereas the cells transfected with an empty vector (ghrelin NC) had a low ghrelin expression that was similar to the control untransfected 

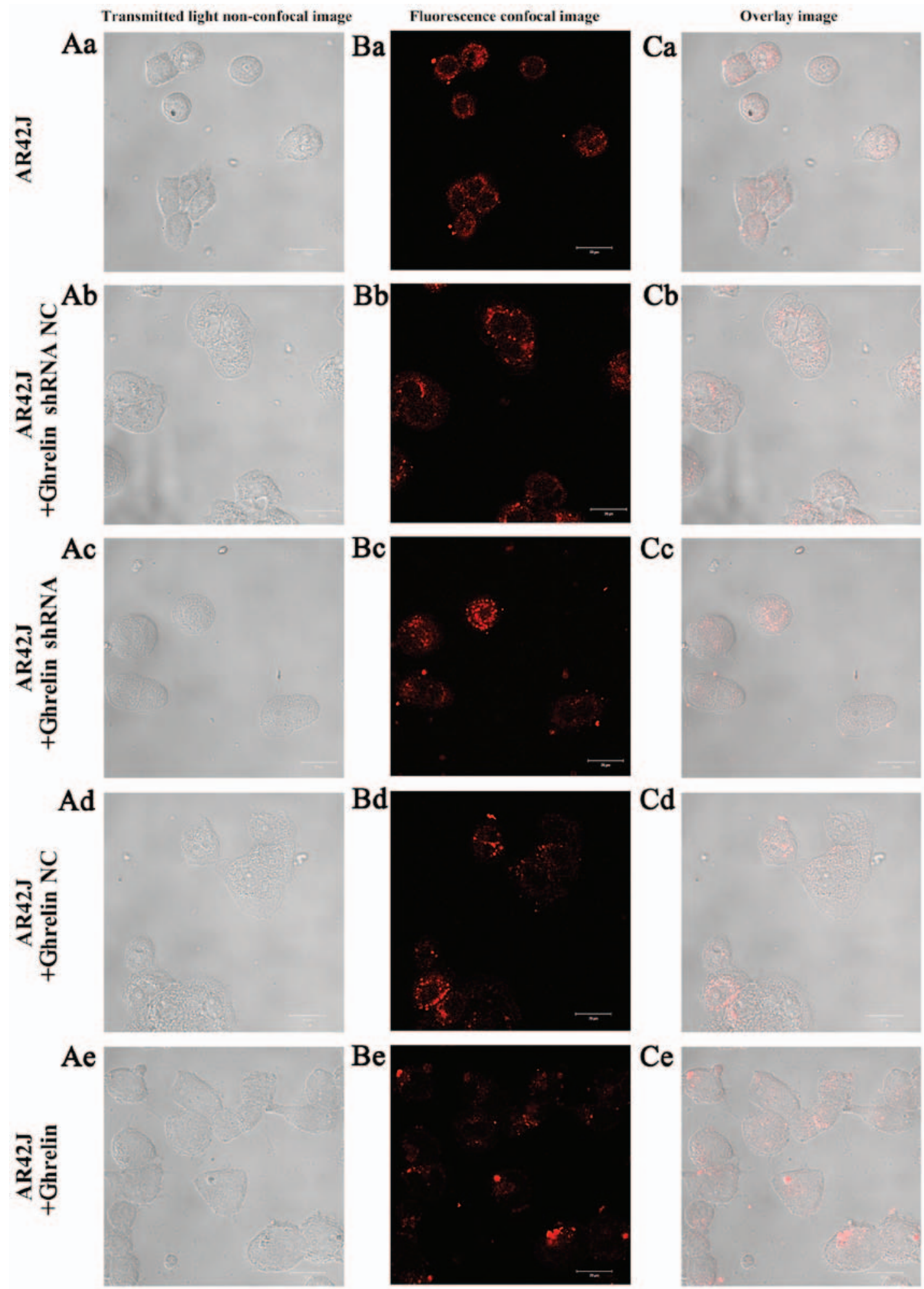

Figure 5. The $\left[\mathrm{Ca}^{2+}\right]_{\text {i }}$ imaging in AR42J cells with ghrelin overexpression and knockdown. (Aa-e) A transmitted light non-confocal image of the acinar cell doublet. (Ba-e) Fluorescence confocal image of cells revealing red fluorescence accumulated in vacuoles. (Ca-e) Overlay of the transmitted light non-confocal image and fluorescence confocal image.

AR42J cells $(\mathrm{p}<0.05)$ (Fig. 3B). Furthermore, in this study, control untransfected AR42J cells had low Cav 2.2 expression. Compared with the control untransfected AR42J cells, Cav 1.2 and Cav 2.2 expression decreased in AR42J cells with ghrelin knockdown, whereas the expression of these calcium channels was increased in AR42J cells with ghrelin overexpression $(\mathrm{p}<0.05)$ (Fig. 4). Collectively, these results indicate that endogenous ghrelin changes the expression of calcium channels in AR42J cells.

The $\left[\mathrm{Ca}^{2+}\right]_{i}$ imaging in AR42J cells with ghrelin overexpression and knockdown. The $\left[\mathrm{Ca}^{2+}\right]_{\mathrm{i}}$ imaging of AR42J cells showed that red fluorescence was similar between the untransfected AR42J cells and two groups of NC transfected cells (Fig. 5). 
Red fluorescence was weakened in the ghrelin knockdown AR42J cells but increased in cells with ghrelin overexpression. These results collectively suggest that a difference in ghrelin expression could affect the $\left[\mathrm{Ca}^{2+}\right]_{\mathrm{i}}$ in AR42J cells.

\section{Discussion}

AP is a relatively common inflammatory disorder of the pancreas. Though most cases of AP are of the MAP type, which is a self-limiting disease, SAP accounts for substantial additional morbidity, with mortality rates as high as $10-20 \%$ (28).

Many molecular signaling pathways, such as intra-acinar trypsinogen activation, local inflammation, systemic inflammatory response, intra-acinar $\mathrm{NF}-\kappa \mathrm{B}$ activation, abnormal intracellular calcium $\left[\mathrm{Ca}^{2+}\right] \mathrm{i}$, mitochondrial dysfunction, autophagy, ER stress and oxidative stress, have been proposed to play a role in the etiology of pancreatic cellular injury in acute pancreatitis (29). Among these possible pathways, $\mathrm{Ca}^{2+}$ overload induced by abnormal $\left[\mathrm{Ca}^{2+}\right]_{\mathrm{i}}$ is receiving increasing attention as an important molecular change in the pathogenesis of acute pancreatitis (11). $\mathrm{Ca}^{2+}$ entry pathway was previously described to be provided by voltage-dependent $\mathrm{Ca}^{2+}$ channels, including L-, N-, T-, P- and R-type $\mathrm{Ca}^{2+}$ channels (30). Of these channels, L-type calcium channels may play a critical role in enhancing the selectivity and regulating specific targets via complexes with $\mathrm{G}$ protein-coupled receptors; $\mathrm{N}$-type $\mathrm{Ca}^{2+}$ channels are thought to directly interact with proteins of the synaptic vesicle docking and fusion machinery (31). As proposed by Gerasimenko et al (32), a $\mathrm{Ca}^{2+}$ channel blocker has been proven useful in preventing the premature digestive enzyme activation, vacuolization, skeletal disruption and pancreatic acinar cell necrosis induced by $\mathrm{Ca}^{2+}$ overload (33).

The aim of this study was to examine the role of endogenous ghrelin in the expression of Cav 1.2 (L-type of $\mathrm{Ca}^{2+}$ channel) and Cav 2.2 (N-type of $\mathrm{Ca}^{2+}$ channel) in acute pancreatitis. For this purpose, we established AEP and ANP rat models, which were induced by caerulein and sodium taurocholate, respectively. In this study, the expression of Cav 1.2 was higher in ANP rats compared with other groups; however, the expression of Cav 2.2 showed no difference between the groups. These results indicate that $\mathrm{Cav} 1.2$ has a potential role in the $\mathrm{Ca}^{2+}$ overload in acute pancreatitis. Additionally, in this study, ghrelin serum levels in ANP rats were higher than those in other groups, as were the IL- $1 \beta$ and TNF- $\alpha$ serum levels. Ghrelin serum levels in AEP rats were also higher than control and normal rats. Collectively, these results indicate that endogenous ghrelin is involved in acute pancreatitis development and may influence the severity of pancreatitis.

In clinical studies, the ghrelin serum level was not found to be a predictor of the severity of disease; however, its combination with the Gastroparesis Cardinal Symptom Index improved its predictive accuracy $(34,35)$. Other studies reported that ghrelin could be implicated in the natural protection of the pancreatic tissue through the activation of the innate immune system to prevent the development of the inflammatory process in the pancreas. This protective pancreatic effect appears to be indirect and depends on the release of $\mathrm{GH}$ and insulin-like growth factor-1 by ghrelin $(23,36,37)$. Our study used AR42J cells, which have many characteristics of normal pancreatic acinar cells and have been used as an in vitro model to study pancreatic acinar cellular secretion, proliferation, and apoptosis $(38,39)$. Previous study showed that ghrelin increases $\left[\mathrm{Ca}^{2+}\right]_{\mathrm{i}}$ through activated L-type $\mathrm{Ca}^{2+}$ channel expression (22). This study performed the knockdown and overexpression of ghrelin in AR42J cells, which retained many characteristics of normal pancreatic acinar cells, such as the synthesis and secretion of digestive enzymes. The expression of Cav 1.2 and Cav 2.2 decreased following ghrelin knockdown; however, the expression of these two calcium channels increased in the ghrelin-overexpressing AR42J cells. Additionally, $\left[\mathrm{Ca}^{2+}\right]_{\mathrm{i}}$ showed the same trend as ghrelin expression in AR42J cells.

In conclusion, our results suggest that $\mathrm{Cav} 1.2$ and Cav 2.2 expression are increased in ANP rats and that serum ghrelin levels may be involved in the severity of acute pancreatitis. Additionally, the $\left[\mathrm{Ca}^{2+}\right]_{\mathrm{i}}$ levels mediated by $\mathrm{Cav} 1.2$ and Cav 2.2 expression are regulated by ghrelin expression in pancreatic acinar cells, at least in part. Nevertheless, the molecular implications of ghrelin-mediated $\left[\mathrm{Ca}^{2+}\right]_{\mathrm{i}}$ regulation in the acute pancreatitis remain to be elucidated.

\section{Acknowledgements}

Not applicable.

\section{Funding}

This study was supported by grants from the National Natural Science Foundation of China (nos. 81060043 and 81260087) and Self-Raised Topic of the Guangxi Zhuang Autonomous Region Health Department (no. Z2012105).

\section{Availability of data and material}

The datasets used and analyzed during the current study are available from the corresponding author on reasonable request.

\section{Authors' contributions}

MQ and GT conceived and designed the study. HW, JH, HF, HS performed the animal experiments. JZ, MQ and ZL performed the cell experiments. JZ and MQ wrote the manuscript. All authors read and approved the final manuscript.

\section{Ethics approval and consent to participate}

All animal care and studies were conducted in accordance with the approval of the Medical Ethics Committee of the First Affiliated Hospital of Guangxi Medical University for Ethical Approval for Research Involving Animals (Nanning, China; permit no. KY-113)

\section{Consent for publication}

Not applicable.

\section{Competing interests}

The authors declare that they have no competing interests. 


\section{References}

1. Yadav D and Lowenfels AB: The epidemiology of pancreatitis and pancreatic cancer. Gastroenterology 144: 1252-1261, 2013.

2. Peery AF, Dellon ES, Lund J, Crockett SD, McGowan CE, Bulsiewicz WJ, Gangarosa LM, Thiny MT, Stizenberg K, Morgan DR, et al: Burden of gastrointestinal disease in the United States: 2012 update. Gastroenterology 143: 1179-87.e1-3, 2012.

3. Banks PA, Bollen TL, Dervenis C, Gooszen HG, Johnson CD Sarr MG, Tsiotos GG and Vege SS; Acute Pancreatitis Classification Working Group: Classification of acute pancreatitis - 2012: Revision of the Atlanta classification and definitions by international consensus. Gut 62: 102-111, 2013.

4. Kingsnorth A and O'Reilly D: Acute pancreatitis. BMJ 332: 1072-1076, 2006.

5. Feng JY and Li YY: Alteration and role of heat shock proteins in acute pancreatitis. J Dig Dis 11: 277-283, 2010.

6. Petersen $\mathrm{OH}$ and Sutton $\mathrm{R}$ : $\mathrm{Ca}^{2+}$ signalling and pancreatitis: Effects of alcohol, bile and coffee. Trends Pharmacol Sci 27: 113-120, 2006.

7. Sah RP, Dawra RK and Saluja AK: New insights into the pathogenesis of pancreatitis. Curr Opin Gastroenterol 29: 523-530 2013 .

8. Montell C: The latest waves in calcium signaling. Cell 122: 157-163, 2005.

9. Ashby MC and Tepikin AV: Polarized calcium and calmodulin signaling in secretory epithelia. Physiol Rev 82: 701-734, 2002.

10. Carabelli V, Marcantoni A, Comunanza V and Carbone E: Fast exocytosis mediated by T- and L-type channels in chromaffin cells: Distinct voltage-dependence but similar $\mathrm{Ca}^{2+}$-dependence. Eur Biophys J 36: 753-762, 2007.

11. Frick TW: The role of calcium in acute pancreatitis. Surgery 152 (Suppl 1): S157-S163, 2012.

12. Raraty M, Ward J, Erdemli G, Vaillant C, Neoptolemos JP, Sutton $\mathrm{R}$ and Petersen $\mathrm{OH}$ : Calcium-dependent enzyme activation and vacuole formation in the apical granular region of pancreatic acinar cells. Proc Natl Acad Sci USA 97: 13126-13131 2000.

13. Perides G, van Acker GJ, Laukkarinen JM and Steer ML: Experimental acute biliary pancreatitis induced by retrograde infusion of bile acids into the mouse pancreatic duct. Nat Protoc 5: 335-341, 2010.

14. Criddle DN, Raraty MG, Neoptolemos JP, Tepikin AV, Petersen $\mathrm{OH}$ and Sutton R: Ethanol toxicity in pancreatic acinar cells: Mediation by nonoxidative fatty acid metabolites. Proc Natl Acad Sci USA 101: 10738-10743, 2004.

15. Kim JY, Kim KH, Lee JA, Namkung W, Sun AQ, Ananthanarayanan M, Suchy FJ, Shin DM, Muallem S and Lee MG: Transporter-mediated bile acid uptake causes $\mathrm{Ca}^{2+}$-dependent cell death in rat pancreatic acinar cells. Gastroenterology 122: 1941-1953, 2002.

16. Voronina S, Sherwood M, Barrow S, Dolman N, Conant A and Tepikin A: Downstream from calcium signalling: Mitochondria, vacuoles and pancreatic acinar cell damage. Acta Physiol (Oxf) 195: 161-169, 2009.

17. Reed AM, Husain SZ, Thrower E, Alexandre M, Shah A, Gorelick FS and Nathanson MH: Low extracellular pH induces damage in the pancreatic acinar cell by enhancing calcium signaling. J Biol Chem 286: 1919-1926, 2011.

18. López Soto EJ, Agosti F, Cabral A, Mustafa ER, Damonte VM, Gandini MA, Rodríguez S, Castrogiovanni D, Felix R, Perelló M, et al: Constitutive and ghrelin-dependent GHSR 1a activation impairs $\mathrm{CaV} 2.1$ and $\mathrm{CaV} 2.2$ currents in hypothalamic neurons. J Gen Physiol 146: 205-219, 2015.

19. Stojilkovic SS, Tabak J and Bertram R: Ion channels and signaling in the pituitary gland. Endocr Rev 31: 845-915, 2010.

20. Date Y, Kojima M, Hosoda H, Sawaguchi A, Mondal MS, Suganuma T, Matsukura S, Kangawa K and Nakazato M: Ghrelin, a novel growth hormone-releasing acylated peptide, is synthesized in a distinct endocrine cell type in the gastrointestinal tracts of rats and humans. Endocrinology 141: 4255-4261, 2000.
21. Fang H, Hong Z, Zhang J, Shen DF, Gao FF, Sugiyama K, Namba $\mathrm{H}$ and Asakawa T: Effects of ghrelin on the intracellular calcium concentration in rat aorta vascular smooth muscle cells. Cell Physiol Biochem 30: 1299-1309, 2012.

22. Glavaski-Joksimovic A, Jeftinija K, Scanes CG, Anderson LL and Jeftinija S: Stimulatory effect of ghrelin on isolated porcine somatotropes. Neuroendocrinology 77: 367-379, 2003.

23. Warzecha Z, Ceranowicz P, Dembinski A, Cieszkowski J, Kusnierz-Cabala B, Tomaszewska R, Kuwahara A and Kato I: Therapeutic effect of ghrelin in the course of cerulein-induced acute pancreatitis in rats. J Physiol Pharmacol 61: 419-427, 2010.

24. Granata R, Settanni F, Trovato L, Destefanis S, Gallo D, Martinetti M, Ghigo E and Muccioli G: Unacylated as well as acylated ghrelin promotes cell survival and inhibit apoptosis in HIT-T15 pancreatic beta-cells. J Endocrinol Invest 29: RC19-RC22, 2006.

25. Kerem M, Salman B, Ozsoy S, Pasaoglu H, Bedirli A, Haziroglu R and Yilmaz TU: Exogenous ghrelin enhances endocrine and exocrine regeneration in pancreatectomized rats. J Gastrointest Surg 13: 775-783, 2009.

26. Kusske AM, Rongione AJ, Ashley SW, McFadden DW and Reber HA: Interleukin-10 prevents death in lethal necrotizing pancreatitis in mice. Surgery 120: 284-289, 1996.

27. Friedrichs K, Gluba S, Eidtmann H and Jonat W: Overexpression of p53 and prognosis in breast cancer. Cancer 72: 3641-3647, 1993.

28. Haney JC and Pappas TN: Necrotizing pancreatitis: diagnosis and management. Surg Clin North Am 87: 1431-1446, ix, 2007.

29. Sah RP, Garg P and Saluja AK: Pathogenic mechanisms of acute pancreatitis. Curr Opin Gastroenterol 28: 507-515, 2012.

30. Ertel EA, Campbell KP, Harpold MM, Hofmann F, Mori Y, Perez-Reyes E, Schwartz A, Snutch TP, Tanabe T, Birnbaumer L, et al: Nomenclature of voltage-gated calcium channels. Neuron 25: 533-535, 2000.

31. Hofmann F, Flockerzi V, Kahl S and Wegener JW: L-type CaV1.2 calcium channels: From in vitro findings to in vivo function. Physiol Rev 94: 303-326, 2014.

32. Gerasimenko JV, Gerasimenko OV and Petersen $\mathrm{OH}$ : The role of $\mathrm{Ca}^{2+}$ in the pathophysiology of pancreatitis. J Physiol 592: 269-280, 2014.

33. Petersen O: Can specific calcium channel blockade be the basis for a drug-based treatment of acute pancreatitis? Expert Rev Gastroenterol Hepatol 8: 339-341, 2014.

34. Türkoğlu A, Böyük A, Tanrıverdi MH, Gündüz E, Dusak A, Kaplan İ and Gümüs M: The potential role of BMI, plasma leptin, nesfatin-1 and ghrelin levels in the early detection of pancreatic necrosis and severe acute pancreatitis: A prospective cohort study. Int J Surg 12: 1310-1313, 2014.

35. Wu LM, Premkumar R, Phillips AR, Windsor JA and Petrov MS: Ghrelin and gastroparesis as early predictors of clinical outcomes in acute pancreatitis. Pancreatology 16: 181-188, 2016.

36. Jaworek J: Ghrelin and melatonin in the regulation of pancreatic exocrine secretion and maintaining of integrity. J Physiol Pharmacol 57 (Suppl 5): 83-96, 2006.

37. Dembiński A, Warzecha Z, Ceranowicz P, Cieszkowski J, Pawlik WW, Tomaszewska R, Kuśnierz-Cabala B, Naskalski JW, Kuwahara A and Kato I: Role of growth hormone and insulinlike growth factor-1 in the protective effect of ghrelin in ischemia/reperfusion-induced acute pancreatitis. Growth Horm IGF Res 16: 348-356, 2006.

38. Christophe J: Pancreatic tumoral cell line AR42J: An amphicrine model. Am J Physiol 266: G963-G971, 1994.

39. Masamune A, Sakai Y, Satoh A, Fujita M, Yoshida M and Shimosegawa T: Lysophosphatidylcholine induces apoptosis in AR42J cells. Pancreas 22: 75-83, 2001. 